\title{
Penegakan Sanksi Administrasi Terhadap Aparatur Sipil Negara Terpidana Korupsi di Kementerian Keuangan
}

\author{
Sutrisno $^{1}$ \\ ${ }^{1}$ Biro Sumber Daya Manusia Kementerian Keuangan \\ Corresponding author. Email : sutris.ihwan@gmail.com
}

Naskah diterima: 12-08-2020 revisi: 20-11-2020; disetujui: 18-05-2021

DOI: https://doi.org/10.46257/jrh.v25i1.132

\begin{abstract}
Abstrak
Berdasarkan data Komisi Pemberantasan Korupsi, pada tahun 2017 sebanyak 43 kasus dari total 123 kasus korupsi di Indonesia atau sekitar 35\% dilakukan oleh Aparatur Sipil Negara dan. merupakan profesi dengan jumlah tindak pidana korupsi terbanyak pada tahun 2017. Kepala Badan Kepegawaian Negara pada tanggal 4 September 2018 mengatakan bahwa terdapat 2.674 Pegawai Negeri Sipil dengan putusan pidana korupsi inkracht, namun 2.357 orang tidak diberhentikan. Rumusan masalah pokok yaitu bagaimana penegakan hukum terhadap Aparatur Sipil Negara Terpidana Korupsi di Indonesia, dan bagaimana pelaksanaan sanksi administrasi terhadap Aparatur Sipil Negara Terpidana Korupsi di Kementerian Keuangan. Tujuan penelitian dilakukan untuk mengkaji penegakan hukum dan praktik pelaksanaan sanksi administrasi terhadap Aparatur Sipil Negara terpidana korupsi. Metode penelitian dilakukan melalui pendekatan yuridis normatif. Hasil penelitian, bahwa Aparatur Sipil Negara terpidana korupsi harus dijatuhi sanksi administrasi berupa Pemberhentian Tidak Dengan Hormat berdasarkan Pasal 87 ayat (4) Undang-Undang Nomor 5 Tahun 2014 tentang Aparatur Sipil Negara dan ditegaskan kembali dalam Putusan Mahkamah Konstitusi. Undang-Undang Nomor 5 Tahun 2014 telah mengamanatkan dibentuknya Peraturan Pemerintah yang mengatur tentang disiplin Aparatur Sipil Negara. Namun saat ini Peraturan Pemerintah tersebut belum ditetapkan dan masih berlaku Peraturan Pemerintah Nomor 53 Tahun 2010 yang sudah tidak sesuai dengan semangat Undang-Undang Nomor 5 Tahun 2014. Aparatur Sipil Negara terpidana korupsi di Kementerian Keuangan dijatuhi sanksi sesuai Pasal 87 ayat (4) yaitu Pemberhentian Tidak Dengan Hormat. Selain itu, Aparatur Sipil Negara yang terbukti melakukan Penyalahgunaan Jabatan/Wewenang dijatuhi sanksi Pemberhentian Dengan Hormat Tidak Atas Permintaan Sendiri meskipun penyalahgunaan wewenang tersebut tidak sampai pada proses pidana. Kesimpulan penegakan sanksi administrasi yaitu berupa Pemberhentian Tidak Dengan Hormat.
\end{abstract}

Kata kunci: aparatur sipil negara, terpidana korupsi, sanksi administrasi, pemberhentian tidak dengan hormat, kementerian keuangan. 


\title{
Administrative Law Enforcement against Civil Servants who was Convicted of Corruption at the Ministry of Finance
}

\begin{abstract}
Based on The Corruption Eradication Commission data's, in 2017 as many as 43 cases out of 123 cases of corruption in Indonesia or about $35 \%$ were committed by the Civil Servants and. is the profession with the highest number of criminal acts of corruption in 2017. The head of the National Civil Service Agency on September 4th 2018 said that there were 2,674 Civil Servants with criminal corruption convictions on inkracht, but 2,357 not dismissed. The main problems are how is law enforcement against Civil Servants who was convicted of corruption in Indonesia and the implementation of administrative sanctions against Civil Servants who was convicted of corruption in Ministry of Finance. The research conducted to findout about law enforcement and the practice of implementing administrative sanctions against civil servants who was convicted of corruption. The research uses normative-juridical approach methode. Based on the result, Civil Servants who was convicted of corruption must be subject to administrative sanctions of Disrespectful Dismissal based on Article 87 paragraph (4) of Law Number 5/2014 and reaffirmed in the Constitutional Court decision. Law Number 5/2014 has mandated the establishment of a Government Regulation about the discipline of the Civil Servants. However, this Government Regulation hasn't been established and still applies Government Regulation Number 53/2010 which is no longer in accordance with the spirit of Law Number 5 Year 2014. Civil Servants who was convicted of corruption at the Ministry of Finance are subject to sanctions in accordance with Article 87 paragraph(4), namely Disrespectful Dismissal. In addition, Civil Servants who are proven to have misused their position / authority will be subject to sanctions with Respectfully Dismissed Without Their Own Request, even the abuse of authority doesn't end in criminal proceess. The conclusion of the enforcement of administrative sanctions is the form of Disrespectful Dismissal.
\end{abstract}

Keywords: civil servants, convicted of corruption, administrative punishment, disrespectful dismissal, ministry of finance.

\section{Pendahuluan}

Pegawai Aparatur Sipil Negara (ASN) sebagaimana diatur dalam UndangUndang Nomor 5 Tahun 2014 tentang Aparatur Sipil Negara (UU ASN)terdiri dari Pegawai Negeri Sipil (PNS) dan Pegawai Pemerintah dengan Perjanjian Kerja (PPPK). PNS diangkat sebagai Pegawai ASN secara tetap untuk menduduki jabatan pemerintahan, sedangkan PPPK diangkat berdasarkan 
perjanjian kerja untuk jangka waktu tertentu dalam rangka melaksanakan tugas pemerintahan. ASN diberikan tugas dalam jabatan pemerintahan atau tugas negara lain, dan diberikan penghasilan berdasarkan peraturan perundangundangan. Tugas yang diserahkan kepada Pegawai ASN antara lain pelaksanaan tugas pelayanan publik, tugas pemerintahan, atau tugas pembangunan tertentu.

Berbeda dengan peraturan perundang-undangan sebelumnya, dalam UU ASN disebutkan secara jelas bahwa untuk menjalankan tugas yang diserahkan kepadanya, ASN harus memiliki integritas, profesional, netral dan bebas dari intervensi politik, bersih dari praktik korupsi, kolusi, dan nepotisme, serta mampu menyelenggarakan pelayanan publik, serta mampu menjadi unsur perekat persatuan dan kesatuan bangsa sesuai dengan Pancasila dan UUD 1945. ASN merupakan profesi yang berlandaskan prinsip-prinsip: nilai dasar; kode etik dan kode perilaku; komitmen, integritas moral, dan tanggung jawab pada pelayanan publik; kompetensi yang diperlukan sesuai dengan bidang tugas; kualifikasi akademik; jaminan perlindungan hukum dalam melaksanakan tugas; dan profesionalitas jabatan.

Perubahan paradigma tentang profesi ASN tersebut juga disertai dengan sistem penggajian dan remunerasi yang lebih baik. Pemberian penghasilan yang lebih baik salah satunya dilakukan dengan tujuan sebagai upaya untuk mencegah dan mengurangi terjadinya praktik korupsi (Moh. Mahfud MD, 2000). Namun demikian, upaya perubahan yang telah dilakukan tersebut tidak sepenuhnya mampu menghilangkan praktik korupsi yang dilakukan oleh ASN. Berdasarkan data korupsi yang dikeluarkan Komisi Pemberantasan Korupsi, sepanjang tahun 2017 sebanyak 43 kasus dari total 123 kasus korupsi di Indonesia atau sekitar 35\% dilakukan oleh ASN. Profesi ASN merupakan profesi dengan jumlah tindak pidana korupsi terbanyak pada tahun 2017.

Sanksi adalah bagian yang sangat penting dalam hukum. Kewajiban atau larangan yang diatur dalam perundang-undangan, tidak akan berguna apabila kewajiban atau larangan tersebut pelaksanaannya tidak dapat dipaksakan (Hadjon \& Dkk, 2018:245). Pemberian sanksi kepada ASN, khususnya pelaku korupsi diatur pada Pasal 87 ayat (2) dan ayat (4) UU ASN. 
Pasal 87 ayat (2) UU ASN mengatur bahwa PNS yang dihukum pidana penjara berdasarkan putusan inkracht dengan hukuman paling singkat 2 tahun dan pidana yang dilakukan tidak berencana, dapat diberhentikan dengan hormat atau tidak diberhentikan. Pasal 87 ayat (4) mengatur PNS diberhentikan tidak dengan hormat antara lain apabila dihukum penjara atau kurungan karena melakukan tindak pidana kejahatan jabatan atau tindak pidana kejahatan yang ada hubungannya dengan jabatan, dan/atau pidana umum dengan pidana penjara paling singkat 2 tahun dan pidana yang dilakukan dengan berencana. Ketentuan dimaksud juga telah dijelaskan dengan lebih lengkap dan jelas dalam Peraturan Pemerintah Nomor 11 Tahun 2017 tentang Manajemen Pegawai Negeri Sipil.

Dalam praktiknya dalam penegakan disiplin terhadap ASN terpidana korupsi terjadi beberapa penyimpangan. Kepala BKN pada hari Selasa, 4 September 2018 (Pernyataan Pers Kepala BKN), mengatakan bahwa berdasarkan data Kemenkum HAM, terdapat 7.749 PNS yang terlibat korupsi dengan 2.674 orang telah dipidana dengan putusan pengadilan yang inkracht. Namun ternyata dari 2.674 orang tersebut, sebanyak 2.357 orang diantaranya tidak diberhentikan.

Metode penelitian dilakukan melalui pendekatan yuridis normatif dengan lokasi penelitian pada Kementerian Keuangan. Pemilihan Kementerian Keuangan sebagai lokasi penelitian karena merupakan instansi yang memiliki tugas untuk membantu Presiden dalam menyelenggarakan urusan pemerintahan di bidang keuangan negara (Sibuea, 2002). Dengan tugas dan fungsi yang berkaitan erat dengan pengelolaan keuangan negara, baik penerimaan negara maupun pengeluaran negara, serta jumlah pegawai yang berjumlah 81.189 pegawai per tanggal 1 Juli 2020, faktor risiko untuk terjadinya tindak pidana korupsi juga lebih tinggi. Oleh karena itu, pengawasan serta penegakan sanksi kepada pelaku korupsi di Kementerian Keuangan harus dilaksanakan dengan lebih tegas (Komisi Aparatur Sipil Negara, 2020).

Berdasarkan latar belakang penulisan yang telah disampaikan, penulis merumuskan beberapa rumusan masalah yang akan dibahas, yaitu:

a. Bagaimana penegakan hukum terhadap Aparatur Sipil Negara Terpidana 
Korupsi di Indonesia?

b. Bagaimana pelaksanaan sanksi administrasi terhadap Aparatur Sipil Negara Terpidana Korupsi di Kementerian Keuangan?

\section{Pembahasan}

\section{A. Penegakan Hukum terhadap Aparatur Sipil Negara Terpidana Korupsi}

Secara umum korupsi diterjemahkan sebagai suatu atau penyalahgunaan uang negara untuk mendapatkan keuntungan pribadi, orang lain, maupun korporasi. Definisi korupsi tidak secara langsung ditulis dalam Undang-Undang Pemberantasan Tindak Pidana Korupsi. Namun dapat diketahui bahwa unsurunsur korupsi terdiri dari: 1) setiap orang atau korporasi; 2) secara melawan hukum melakukan perbuatan atau menyalahgunakan kewenangan, kesempatan atau sarana yang ada padanya karena jabatan atau kedudukan; 3) memperkaya diri sendiri, orang lain atau korporasi; 4) merugikan keuangan negara atau perekonomian negara (Komisi Pemberantasan Korupsi, 2006).

ASN yang dijatuhi pidana karena tindak pidana korupsi, dijatuhi sanski administrasi berupa Pemberhentian Tidak Dengan Hormat (PTDH) karena memenuhi Pasal 87 ayat (4) UU ASN. Perbuatan tersebut termasuk tindak pidana kejahatan jabatan atau tindak pidana kejahatan yang ada hubungannya dengan jabatan. Namun dalam praktiknya di banyak instansi pemerintah di Indonesia, baik pusat maupun daerah, banyak digunakan ketentuan Pasal 87 ayat (2) UU ASN sehingga terdapat pilihan untuk diberhentikan dengan hormat atau tidak diberhentikan (Sudrajat, 2017).

Ketentuan Pasal 87 ayat (4) UU ASN pernah diuji di Makamah Konstitusi melalui perkara dengan nomor 87/PUU-XVI/2018. Dalam amar putusannnya, Mahkamah Konstitusi memberikan pertimbangan dan memutuskan bahwa terhadap ASN yang dipidana berdasarkan keputusan yang inkracht karena melakukan korupsi dijatuhi sanski PTDH karena memenuhi Pasal 87 ayat (4) UU ASN. Penerapan PTDH sebagaimana diatur dalam Pasal 87 ayat (4), bukan merupakan sanksi tambahan, sehingga tidak harus dicantumkan dalam putusan 
pengadilan. Pejabat Pembina Kepegawaian tidak mempunyai pilihan selain PTDH.

Hukuman tindak pidana yang berhubungan dengan jabatan menjadi harus diperberat karena jabatan merupakan amanah dari negara. ASN diangkat dipilih dalam jabatan dianggap sebagai ASN terbaik. ASN tersebut harus dapat dijadikan teladan dan menunjukan perilaku dan martabat yang lebih baik. ASN juga wajib mematuhi etika profesi dan menjalankan jabatan secara hati-hati karena dalam jabatan tersebut terdapat konsekuensi hukum dan sanksi yang berat.

Sebagaimana amanat Pasal 86 ayat (3) dan Pasal 89 UU ASN, pengaturan teknis mengenai tata cara dan metode penjatuhan hukuman disiplin terhadap ASN akan diatur dalam Peraturan Pemerintah (PP). Namun demikian sampai dengan saat ini, 6 tahun setelah UU ASN ditetapkan, PP tersebut belum juga ditetapkan. Peraturan yang masih berlaku saat ini adalah PP Nomor 53 Tahun 2010.

PP Nomor 53 Tahun 2010 yang digunakan dalam penjatuhan hukuman disiplin ASN sudah tidak sesuai dengan semangat serta amanat UU ASN. Dalam PP Nomor 53 Tahun 2010, ketentuan penjatuhan hukuman disiplin bagi ASN yang melakukan tindak pidana tidak diatur secara tegas.

Penjatuhan hukuman disiplin karena penyalahgunaan wewenang tidak diatur dengan tegas jenis hukuman disiplin yang diberikan. Tidak ada ketegasan bahwa penyalahgunaan wewenang dijatuhi hukuman disiplin PTDH. Ketidaktegasan tersebut menyebabkan Pejabat Pembina Kepegawaian dapat memilih salah satu dari 5 jenis hukuman yang ditetapkan, sehingga ASN yang telah dijatuhi hukuman pidana korupsi dapat tidak diberhentikan dan diangkat kembali menjadi ASN setelah yang bersangkutan selesai menjalani hukuman pidana. Hal tersebut menyebabkan dari 2.674 orang ASN telah dipidana korupsi dengan putusan pengadilan yang sudah inkracht, sebanyak 2.357 orang diantaranya tidak diberhentikan.

Pasal 87 ayat (2) UU ASN merupakan sanksi yang diberikan terhadap PNS yang melakukan tindak pidana umum dan dengan tidak berencana. Pejabat 
Pembina Kepegawaian dapat memberhentikan dengan hormat atau tidak memberhentikannya. Pejabat Pembina Kepegawaian diberikan pertimbangan untuk melakukan pemberhentian dengan hormat atau mengenakan sanksi lain terhadap PNS tersebut. Namun demikian, Pejabat Pembina Kepegawaian tetap memiliki batasan PP Nomor 53 Tahun 2010. PNS tersebut dapat tidak diberhentikan perbuatan pidananya dianggap tidak menurunkan harkat dan martabat, memiliki prestasi kerja baik, tidak berpengaruh pada lingkungan kerja, dan masih terdapat formasi.

Praktik tersebut bertentangan dengan ketentuan Pasal 87 ayat (4) huruf b UU ASN. Korupsi termasuk dalam kejahatan jabatan sehingga pelaku harus dijatuhi PTDH.

Terdapat beberapa faktor yang mempengaruhi keberhasilan penegakan hukum yaitu: 1) hukum (undang-undang); 2) penegak hukum, termasuk pembentuk hukum; 3) sarana atau fasilitas pendukung; 4) masyarakat dimana hukum tersebut diterapkan; dan 5) faktor kebudayaan (Soekanto, 2011:5). Tindakan yang diambil oleh Pejabat Pembina Kepegawaian tersebut tidak dapat disalahkan sepenuhnya. Hal tersebut dikarenakan terdapat kekosongan hukum dimana Peraturan Pemerintah sebagai pelaksanaan teknis penjatuhan hukuman disiplin sebagai amanat UU ASN sampai dengan saat ini belum ditetapkan sehingga Pejabat Pembina Kepegawaian menggunakan PP Nomor 53 Tahun 2010 untuk menjatuhkan hukuman disiplin terhadap ASN pelaku korupsi, sehingga Pejabat Pembina Kepegawaian dapat memilih salah satu hukuman disiplin yang diatur (Rahardjo, 1983).

Mendagri, MenPAN RB, dan Kepala BKN telah mengeluarkan Keputusan Bersama Nomor 182/6597/SJ, Nomor 15 Tahun 2018, dan Nomor 153/KEP/2018 tanggal 13 September 2018. Keputusan Bersama tersebut merupakan upaya percepatan penyelesaian PTDH kepada ASN laku korupsi.

Komisi Aparatur Sipil Negara melakukan monitoring pelaksanaan PTDH tersebut. Hasilnya per tanggal 4 Maret 2020 masih banyak Pejabat Pembina Kepegawaian tidak segera melakukan PTDH. Hanya 1.262 (53.5\%) PNS yang telah dijatuhi PTDH, sisanya 1.095 (46.5\%) PNS belum dijatuhi PTDH, bahkan 
ada yang diangkat dalam jabatan Pimpinan Tinggi Pratama. Terdapat 7 (tujuh) alasan Pejabat Pembina Kepegawaian yang mendasari fakta tersebut:

1. Konflik Kepentingan

Beberapa ASN terpidana korupsi memiliki hubungan dekat dengan Pejabat Pembina Kepegawaian atau merupakan anggota tim sukses saat pemilihan Kepala Daerah yang menjadi Pejabat Pembina Kepegawaian.

2. Tuntutan Ganti Rugi

Banyak PNS terpidana korupsi telah memasuki masa pensiun atau meninggal dunia, dengan tetap diberikan gaji atau pensiun. Pejabat Pembina Kepegawaian khawatir dapat dikenakan tuntutan ganti rugi apabila melakukan PTDH.

3. Belum Mendapatkan Putusan

Putusan pengadilan yang inkracht belum diterima oleh Pejabat Pembina Kepegawaian sehingga belum dilakukan PTDH.

4. Uji Materi Mahkamah Konstitusi

Beberapa Pejabat Pembina Kepegawaian menunggu hasil uji materi UU ASN di Makamah Konstitusi. Menurut pandangan penulis, alasan tersebut tidak dapat diterima karena uji materi Pasal 87 ayat (4) telah diputus oleh Mahkamah Konstitusi dengan Putusan Nomor 87/PUU-XVI/2018 tanggal 25 April 2019.

5. Enggan Berurusan dengan Pengadilan Tata Usaha Negara PNS terpidana korupsi yang dijatuhi PTDH oleh Keputusan Pejabat Pembina Kepegawaian dapat mengajukan banding ke Pengadilan Tata Usaha Negara, sehingga mempengaruhi Pejabat Pembina Kepegawaian yang lain untuk menerbitkan keputusan PTDH.

6. Rasa Kasihan

Pejabat Pembina Kepegawaian tidak melakukan PTDH karena alasan kemanusiaan. PNS terpidana korupsi telah dijatuhi hukuman penjara, dan mengganti kerugian negara. PTDH dirasa dapat menambah penderitaan PNS terpidana korupsi.

7. Mutasi dari Instansi Lain 
Beberapa PNS terpidana korupsi merupakan mutasi dari instansi lainnya dan telah selesai menjalani hukuman sebelum yang bersangkutan dipindahkan.

\section{B. Pelaksanaan Sanksi Administrasi terhadap Aparatur Sipil Negara di Kementerian Keuangan}

1. PTDH ASN Kementerian Keuangan Terpidana Korupsi

Kementerian Keuangan memiliki tugas membantu Presiden dalam penyelenggaraan urusan pemerintahan bidang keuangan negara, dan menjalankan beberapa fungsi di bidang anggaran, perpajakan, kepabeanan dan cukai, perbendaharaan, kekayaan negara, perimbangan keuangan, dan pengelolaan pembiayaan dan risiko. Dengan tugas dan fungsi berkaitan erat dengan pengelolaan keuangan negara, baik penerimaan negara maupun pengeluaran negara, serta jumlah pegawai yang berjumlah 81.189 pegawai per tanggal 1 Juli 2020, faktor risiko untuk terjadinya tindak pidana korupsi juga lebih tinggi. Pengawasan serta penegakan sanksi terhadap pelaku korupsi di Kementerian Keuangan dilaksanakan dengan lebih tegas. (Rahardjo, 2009)

Berdasarkan hasil penelitian, ASN Kementerian Keuangan terpidana korupsi dengan putusan inkraht akan dijatuhi sanksi PTDH berdasarkan Pasal 87 ayat (4) UU ASN. Sepanjang tahun 2018, terdapat 7 orang ASN Kementerian Keuangan yang dijatuhi PTDH sebagai ASN karena melakukan tindak pidana korupsi. Jumlah tersebut turun menjadi 2 orang pada tahun 2019 .

Sebagai salah satu contoh adalah Sdr. R yang merupakan pejabat struktural pada Kantor Pelayanan Pajak. Sdr. Berdasarkan putusan pengadilan, Sdr. R dinyatakan terbukti melakukan tindak pidana korupsi. Kepada Sdr. R dijatuhkan pidana penjara selama 01 (satu) tahun 04 (empat) bulan dan denda Rp 50.000.000,00 subsider 06 (enam) bulan penjara.

Terhadap Sdr. R, Kementerian Keuangan menggunakan ketentuan Pasal 87 ayat (4) UU ASN. Pidana yang dilakukan oleh Sdr. RT merupakan penyalahgunaan jabatan dan dijatuhi hukuman disiplin berupa PTDH. Jika 
digunakan ketentuan Pasal 87 ayat (2) UU ASN atau ketentuan PP Nomor 53 Tahun 2010 sebagaimana praktik yang banyak dilakukan, maka Sdr. R tidak dapat diberhentikan sebagai ASN. Sdr R hanya dapat dijatuhi hukuman disiplin lainnya yang lebih karena hukuman pidana penjara berdasarkan putusan pengadilan kurang dari 2 (dua) tahun.

2. Penjatuhan Hukuman Disiplin karena Penyalahgunaan Jabatan/ Kewenangan

Penyalahgunaan wewenang berdasarkan Undang-Undang Pemberantasan Tindak Pidana Korupsi disebutkan sebagai penyelahgunaan wewenang, kesempatan atau sarana yang melekat pada jabatan, dengan tujuan keuntungan diri sendiri, orang lain atau korporasi dan merugikan negara (Huda, 2005).

Sebelum ditetapkannya Peraturan Pemerintah tentang penjatuhan hukuman disiplin sebagai amanat UU ASN, maka tetap diberlakukan PP Nomor 53 Tahun 2010. Dalam PP Nomor 53 Tahun 2010 hukuman disiplin terdiri dari 3 tingkatan: ringan, sedang, dan berat. Sebagai pelaksanaan, Kementerian Keuangan menerbitkan Peraturan Menteri Keuangan Nomor 124/PMK.09/2011 tentang Penggunaan Metode Penentuan Jenis Hukuman Disiplin (MPJHD) Dalam Rangka Penjatuhan Hukuman Disiplin Pegawai Negeri Sipil di Lingkungan Kementerian Keuangan.

Penetapan Peraturan Menteri Keuangan Nomor 124/PMK.09/2011 dilakukan sebagai upaya Kementerian Keuangan untuk menciptakan ASN yang professional dan bebas dari KKN. Penjatuhan hukuman disiplin di Kementerian Keuangan menggunakan MPJHD untuk menentukan tingkat dan jenis hukuman disiplin yang diberikan dengan menggunakan penilaian angka. Ada beberapa tahapan dalam MPJHD, yaitu:

a. Penentuan Jenis Pelanggaran;

b. Pemilihan Tingkat Hukuman Disiplin dengan pertimbangan latar belakang melakukan serta dampak negatif dari perbuatan yang dilakukan.

c. Perhitungan Nilai Akhir yang merupakan penjumlahan Nilai Pokok dan 
Nilai Tambahan;

1) Nilai Pokok

\begin{tabular}{|c|c|c|c|}
\hline No & Tingkat Hukdis & Rentang Nilai & Nilai Pokok \\
\hline 1 & Ringan & $0<\mathbf{x}<30$ & 0 \\
\hline 2 & Sedang & $30<\mathbf{x}<60$ & 30 \\
\hline 3 & Berat & $60<\mathbf{x}<110$ & 60 \\
\hline
\end{tabular}

2) Nilai Tambahan berdasarkan karakteristik setiap jenis pelanggaran.

a) Pembobotan Tetap berdasarkan jenis hukuman pada PP Nomor 53 Tahun 2010;

b) Pembobotan Utama sesuai dengan latar belakang pelanggaran, jumlah jenis pelanggaran, dan frekuensi pelanggaran dilakukan;

c) Pembobotan Tambahan:

(1) Jumlah kerugian pihak yang dilayani;

(2) Jumlah kerugian negara;

(3) Jumlah uang yang diterima.

d. Konversi Nilai Akhir menjadi Grade;

e. Penetapan jenis hukuman berdasarkan Grade.

\begin{tabular}{|c|l|c|c|}
\hline No & \multicolumn{1}{|c|}{ Jenis Hukdis } & Kategori & Nilai \\
\hline 1 & Teguran Lisan & Ringan-1 & $0<\mathbf{x}<10$ \\
\hline 2 & Teguran Tertulis & Ringan-2 & $10<\mathbf{x}<20$ \\
\hline 3 & Pernyataan Tidak Puas Secara Tertulis & Ringan-3 & $20<\mathbf{x}<30$ \\
\hline 4 & $\begin{array}{l}\text { Penundaan Kenaikan Gaji Berkala } \\
\text { Selama 1 Tahun }\end{array}$ & Sedang-1 & $30<\mathbf{x}<40$ \\
\hline 5 & $\begin{array}{l}\text { Penundaan Kenaikan Pangkat Selama } \\
1 \text { Tahun }\end{array}$ & Sedang-2 & $40<\mathbf{x}<50$ \\
\hline 6 & $\begin{array}{l}\text { Penurunan Pangkat Pada Pangkat yang } \\
\text { Setingkat Lebih Rendah selama 1 } \\
\text { tahun }\end{array}$ & Sedang-3 & $50<\mathbf{x}<60$ \\
\hline 7 & $\begin{array}{l}\text { Penurunan Pangkat Pada Pangkat yang } \\
\text { Setingkat Lebih Rendah selama 3 } \\
\text { tahun }\end{array}$ & Berat-1 & $60<\mathbf{x}<70$ \\
\hline 8 & $\begin{array}{l}\text { Pemindahan Dalam Rangka Penurunan } \\
\text { Jabatan Setingkat Lebih Rendah }\end{array}$ & Berat-2 & $70<\mathbf{x}<80$ \\
\hline 9 & Pembebasan dari Jabatan & Berat-3 & $80<\mathbf{x}<90$ \\
\hline 10 & $\begin{array}{l}\text { Pemberhentian Dengan Hormat Tidak } \\
\text { Atas Permintaan Sendiri sebagai PNS }\end{array}$ & Berat-4 & $90<\mathbf{x}<100$ \\
\hline 11 & PTDH sebagai PNS & Berat-5 & $100<\mathbf{x}<110$ \\
\hline
\end{tabular}


Sebagai contoh, seorang pegawai Sdr. A merupakan Account Representative pada Kantor Pelayanan Pajak. Dalam melaksanakan tugasnya sebagai Account Representative, yang bersangkutan 2 kali membuatkan SPT wajib pajak dengan menerima imbalan berupa uang dengan total sejumlah total Rp 100.000.000.

Tidak ditemukan kerugian negara pada perbuatan Sdr. A tersebut karena jumlah pajak yang telah dibayarkan oleh Wajib Pajak tetap sesuai. Wajib Pajak juga tidak merasa dirugikan. Namun demikian hal tersebut merupakan penyalahgunaan jabatan. Secara rinci, MPJHD dalam kasus tersebut dapat dijabarkan sebagai berikut:

\begin{tabular}{|c|c|c|}
\hline Faktor Penilaian & Bobot & Nilai \\
\hline \multicolumn{3}{|l|}{ Unsur Utama } \\
\hline $\begin{array}{l}\text { Menyalahgunakan Wewenang: Pasal } 4 \text { ayat } 1 \text { PP } \\
53 \text { Tahun } 2010\end{array}$ & $\begin{array}{c}\text { Tingkat } \\
\text { Berat }\end{array}$ & 60 \\
\hline \multicolumn{3}{|l|}{ Unsur Tambahan } \\
\hline 1. Banyaknya jenis pelanggaran (1 jenis) & 1 & 10 \\
\hline 2. Frekuensi pelanggaran yang sama (2 kali) & 0,5 & 5 \\
\hline $\begin{array}{l}\text { 3. Latar belakang pelanggaran (Berinisiatif } \\
\text { melakukan) }\end{array}$ & 1 & 10 \\
\hline 4. Jumlah kerugian pihak yang dilayani $(0)$ & - & 0 \\
\hline 5. Jumlah Kerugian Negara $(0)$ & 0 & 0 \\
\hline 6. Jumlah uang yang diterima $(\mathrm{Rp} 100.000 .000)$ & 0,75 & 7,5 \\
\hline \multicolumn{2}{|l|}{ Nilai Total } & 92,5 \\
\hline
\end{tabular}

ASN Kementerian Keuangan yang terbukti melakukan penyalahgunaan jabatan/wewenang berdasarkan hasil pemeriksaan Tim Pemeriksa, dapat dijatuhi sanksi administratif berupa Pemberhentian Dengan Hormat Tidak Atas Permintaan Sendiri, meskipun penyalahgunaan wewenang tersebut tidak sampai pada proses pidana. Sepanjang tahun 2018, terdapat 39 orang yang dijatuhi Pemberhentian Dengan Hormat Tidak Atas Permintaan Sendiri sebagai ASN karena penyalahgunaan wewenang. Jumlah tersebut turun menjadi 11 orang pada tahun 2019. 


\section{Penutup}

\section{A. Kesimpulan}

Kesimpulan yang dapat diambail berdasarkan hasil penelitian yang dilakukan adalah:

1. ASN terpidana korupsi berdasarkan putusan inkracht wajib dijatuhi sanksi administrasi berupa PTDH karena memenuhi Pasal 87 ayat (4) UU ASN sebagaimana ditegaskan kembali oleh Mahkamah Konstitusi dalam Putusan Nomor 87/PUU-XVI/2018.

2. ASN Kementerian Keuangan yang dijatuhi pidana berdasarkan putusan inkracht karena melakukan tindak pidana korupsi, dijatuhi sanksi administratif berupa PTDH sesuai dengan ketentuan Pasal 87 ayat (4) UU ASN, sedangkan ASN yang terbukti melakukan Penyalahgunaan Jabatan/Wewenang berdasarkan hasil pemeriksaan Tim Pemeriksa, dapat dijatuhi sanksi administrasi berupa Pemberhentian Dengan Hormat Tidak Atas Permintaan Sendiri berdasarkan Metode Penentuan Jenis Hukuman Disiplin Kementerian Keuangan.

\section{B. Saran}

Pejabat Pembina Kepegawaian di instansi pusat maupun daerah sudah seharusnya menjalankan ketentuan Pasal 87 ayat (4) UU ASN sebagaimana ditegaskan dalam Putusan Mahkamah Konstitusi Republik Indonesia Nomor 87/PUU-XVI/2018 dan menjatuhkan hukuman administratif berupa PTDH terhadap ASN yang terbukti dan dijatuhi pidana karena melakukan tindak pidana korupsi.

\section{Daftar Pustaka}

Anti-Corruption Clearing House (ACCH) KPK. (2020). Tindak Pidana Korupsi berdasarkan Profesi/Jabatan. Diambil 11 Juli 2020, dari Anti-Corruption Clearing House (ACCH) KPK website: https://acch.kpk.go.id/id/ statistik/tindak-pidana-korupsi/tpk-berdasarkan-profesi-jabatan 
Hadjon, P. M., \& Dkk. (2018). Pengantar Hukum Administrasi Negara Indonesia. Surabaya: Yuridika.

Huda, N. (2005). Hukum Tata Negara Indonesia; Edisi Revisi. Jakarta: PT Raja Grafindo Persada.

Kepala Badan Kepegawaian Negara. (2018). Pernyataan Pers pada hari Selasa tanggal 4 September 2018. Diambil 11 Desember 2020, dari Detik Com website: https://news.detik.com/berita/d-4196562/kpk-harap-asn-terbuktikorupsi-segera-dipecat?_ga=2.56401896.2118806393.1544 5089981814227224.1542332472

Komisi Aparatur Sipil Negara. (2020). 7 Alasan PPK belum melakukan PTDH Terhadap ASN Berstatus Terpidana Korupsi. Diambil 4 Agustus 2020, dari Komisi Aparatur Sipil Negara website: https://www.kasn.go.id/details/item/368-7-alasan-ppk-belum-melakukanptdh-terhadap-asn-berstatus-terpidana-korupsi

Komisi Pemberantasan Korupsi. (2006). Memahami untuk Membasmi; Buku Panduan untuk Memahami Tindak Pidana Korupsi. Jakarta: Komisi Pemberantasan Korupsi.

Moh. Mahfud MD. (2000). Dasar dan Struktur Ketatanegaraan Indonesia. Jakarta: Rineka Cipta.

Rahardjo, S. (1983). Masalah Penegakan Hukum. Bandung: Sinar Baru.

Rahardjo, S. (2009). Penegakan Hukum Suatu Tinjauan Sosiologis. Yogyakarta: Genta Publishing.

Republik Indonesia. Peraturan Menteri Keuangan Nomor 124/PMK.09/2011 tentang Penggunaan Metode Penentuan Jenis Hukuman Disiplin dalam Rangka Penjatuhan Hukuman Disiplin Pegawai Negeri Sipil di Lingkungan Kementerian Keuangan.

Republik Indonesia. Peraturan Pemerintah Nomor 11 Tahun 2017 tentang Manajemen Pegawai Negeri Sipil.

Republik Indonesia. Peraturan Pemerintah Nomor 53 Tahun 2010 tentang Disiplin Pegawai Negeri Sipil.

Republik Indonesia. Putusan Mahkamah Konstitusi Nomor 87/PUU-XVI/2018 
tanggal 25 April 2019.

Republik Indonesia. Undang-Undang Dasar Negara Republik Indonesia 1945.

Republik Indonesia. Undang-Undang Nomor 5 Tahun 2014 tentang Aparatur Sipil Negara.

Sibuea, H. P. (2002). Ilmu Negara. Jakarta: Erlangga.

Soekanto, S. (2011). Faktor-Faktor yang Mempengaruhi Penegakan Hukum. Jakarta: PT Raja Grafindo Persada.

Sudrajat, T. (2017). Hukum Birokrasi Pemerintah: Kewenangan dan Jabatan. Jakarta: Sinar Baru. 